\title{
Investigating the Causality Between Remittances, Infant Mortality, and Economic Growth in India: A Cointegration and Vector Error Correction Model
} Analysis

\author{
Hassan Rashid ${ }^{1} \&$ Miguel D. Ramirez ${ }^{1, *}$ \\ ${ }^{1}$ Department of Economics, Trinity College, Hartford, Connecticut 06106, United States \\ *Corresponding author: Department of Economics, Trinity College, Hartford, Connecticut \\ 06106, United States. Tel: 1-959-200-6935. E-mail: muhammadhassan.rashid@trincoll.edu
}

Received: July 6, 2021 Accepted: September 11, $2021 \quad$ Published: September 22, 2021

doi: 10.5296/rae.v13i3.19042ＵRL: https://doi.org/10.5296/rae.v13i3.19042

\begin{abstract}
The main objective of this paper is to analyze the impact of remittances on human development as measured by infant mortality rates and real GDP per capita in India using time series data for the 1975-2018 period. By employing the Zivot-Andrews single-break unit root test and cointegration analysis using the Johansen procedure, a stable long-run relationship is found among the variables. Consequently, by estimating a VECM with dummy variables, results indicate that, in the long run, both remittances and real GDP per capita have a negative and significant impact on infant mortality rates in India. With infant mortality rate as a dependent variable, the adjustment coefficient for the cointegrating vector is negative and significant as the theory predicts. A Granger Block causality test is also conducted, and results indicate that remittances do not Granger cause real GDP and infant mortality rate; however, it is found that infant mortality rate and real GDP per capita Granger cause remittances. Policy implications are discussed.
\end{abstract}

JEL codes: C22, F24, O53

Keywords: Cointegration analysis, vector error correction model, Granger block causality, infant mortality rates, remittances, Zivot-Andrews test 


\section{Introduction}

The International Monetary Fund (IMF) defines remittances as the value of monetary transfers that are sent back from workers living abroad for more than a year to their home country. Remittances are an important source of funding and capital accumulation, and today their impact is more profound in developing countries that rely heavily on remittances. According to the World Bank (2020), remittances to LMICs (Low- and Middle-Income Countries) reached a record $\$ 554$ billion in 2019, after which they declined by $20 \%$ in 2020 due to the economic crisis induced by the COVID-19 pandemic. Even with the decline, The Bank estimates remittances to become even more important as a source of external financing for LMICs as the fall in FDI is expected to be larger due to the pandemic. By 2009, remittances became as large as FDI in some countries, and in 2019 remittance flows to LMICs outgrew FDI. (World Bank, Personal remittances, received (\% of GDP) - India 2021).

In developing countries, remittances play an important role as a source of household income. Each year, South Asian migrant workers send a significant amount of remittances which are an important source of income, stability, and growth (Sutradhar, 2020). According to the World Bank (2019), India was the largest remittance-receiving country in 2018 , with over $\$ 78$ billion USD received. Furthermore, remittances play an important role in financing capital formation. For India, since 1993-1994, remittances have averaged about 7-8\% of gross fixed capital formation (gross investment), and since the 2000s that figure has gone up to at least $10 \%$. This coincides with the introduction of the market exchange rate system in 1993, and various reforms in the 1990s and into the 2000s that relaxed controls on foreign exchange transactions, all of which helped contribute to the remittance surge seen in 2005-2006.

This topic is chosen because of the increasing importance of remittance flows and their ambiguous link to economic growth. Many researchers have conducted several studies on the various aspects of remittances, mostly focusing on the impact of remittances on economic growth, which have generated contradictory results. For example, many studies suggest that remittances have a positive impact on economic growth in developing countries (Azam, 2015; Jouini, 2015; Kumar, 2013; Mundaca, 2009; Ramirez, 2013; Ratha, 2003). Further, Kumar (2013) confirmed that remittances have a positive effect on economic growth in Guyana for the period 1982-2010. Some previous studies have also shown that in developing countries, economic growth and remittances are both correlated (Meyer and Shera, 2017; Rao and Hassan, 2012; Siddique et al., 2012).

However, there are some studies that suggest the opposite, viz., that remittance flows impact economic growth negatively. Amuedo-Dorantes and Pozo (2006) argued that remittances could reduce international competitiveness, thus reducing exports and negatively impacting GDP, and Chami et al. (2003) showed that remittances had a negative effect on economic growth in developing countries with poor economic conditions over the period 1970-1998. There is some economic basis for this idea, viz., remittances can have a negative impact on growth in recipient countries by reducing incentives to work, thus reducing labor supply. Chami et al. (2018) show that remittances reduce labor force participation, while other studies suggest that remittance flows negatively impact long-run economic growth of recipient countries through an 
appreciation of the real exchange rate. This is also called the Dutch disease phenomenon, where a substantial appreciation of the domestic currency harms the country's overall development (Acosta et al., 2009).

There also exists empirical ambiguity regarding the effect of remittances on human development. Hall and Patrinos (2004) found a link between poverty and human development, where lack of expenditure on human development is followed by poverty. Further, through meta-analysis, O'Hare et al. (2013) also found that household income is an important determinant of infant mortality.

Based on this, it is important to investigate whether there is a trade-off between remittances and human development. The objective of this paper is to analyze the relationship between remittances, real GDP per capita (economic growth), and infant mortality rate (a proxy for health) in India. India is chosen because it is the world's top receiver of remittances, and has been for at least the past 15 years. It is also one of the largest developing countries and relies heavily on remittances - in 2018, personal remittances received in India accounted for $10.03 \%$ of GFCF (gross fixed capital formation).

This paper uses causality techniques in a multivariate time series framework, where economic growth, infant mortality, and remittances are all considered to be endogenous variables within the framework of a Vector Error Correction model (VECM). It examines the effect of remittances on two indicators of human development in India from 1975 to 2018, namely real GDP per capita, which assesses economic growth in a country, and the infant mortality rate, which is a proxy measure for the health of the population in a country, defined as the number of infants dying before reaching one year of age, per 1,000 live births in a given year. Cointegration analysis is conducted using the Johansen procedure, after which a VECM is estimated which also includes three dummy variables that account for structural breaks in the series, namely recessions, booms, and policies that impacted both the inflow of remittances to India and the infant mortality rate. Granger Block Exogeneity tests are then employed in order to determine if the variables "Granger cause" each other. Lastly, impulse response functions are generated to trace the responsiveness of the endogenous variables to shocks to each variable.

The rest of the paper is organized as follows: Section II presents a literature review related to the study. Section III presents the empirical model, and Section IV discusses the data gathered. Section V presents and discusses empirical results, including results from causality tests. Section VI discusses problems with the model, while the final section discusses policy implications and provides concluding remarks.

\section{Literature Review}

As indicated above, there is some evidence which suggests remittances favorably impact economic growth. Salahuddin and Gow (2015) find that migrants' remittances play a positive role in spurring economic growth for some of the largest recipient countries, including India, Bangladesh, Pakistan and the Philippines from 1977-2012. Giuliano and Ruiz-Arranz (2009) found that remittances had a significant positive effect on economic growth in developing 
countries for the period 1975-2002. Ratha (2013) also suggests that remittances boost economic growth by encouraging human capital inflows and improving the country's access to international markets. Kumar (2013) explored the effects of remittances on economic growth in Guyana, a developing country in South America, further confirming the positive effect of remittances on economic growth. Adams et al. (2013) use cointegration techniques to find the link between remittances and poverty reduction and investment in human development. Their findings also support the positive effect of remittances in reducing poverty and increasing investments in human development.

Remittances are critical for many households in developing countries, owing to their ability to help reduce poverty. Azizi (2018) and Ustubici and Irdam (2012) find that remittances sent back home resulted in better access to education, health, and social security services. Azizi (2018) also finds that remittances help increase spending on health services and reduce infant mortality. They also help increase the standard of living for many households, including better nutrition and healthcare (Gianetti et al., 2009; Airola, 2007).

Furthermore, using a fixed effect model, Adenutsi (2010) showed that, for developing subSaharan African countries, remittance inflows help increase aggregate expenditure and allow greater access to healthcare facilities to improve the quality of human life. His results revealed that a $10 \%$ increase in remittances increases human development by $0.1 \%$ in the SSA region, because it serves as extra income for families to spend on healthcare and education. Adenutsi's model also assumes that remittances are important in improving human development because they will be spent on basic needs such as education and healthcare (de Haas, 2009). Ustubici and Irdam (2012) conducted a study similar to Adenutsi's but they used a different method to examine how remittances impact human development. By using the OLS procedure, they compare the impact of remittances on human development with the effect of FDI and ODA (Official Development Assistance, an important component of international financing for development and welfare for developing countries) for 32 randomly selected countries. Their results reveal a positive relationship between remittances and human development. They also find that remittances have a higher explanatory power on human development than either FDI or ODA, indicating that remittances go directly to households. This result, complemented by the fact that in 2019 remittance flows to LMICs became larger than FDI, further proves the critical importance that remittances hold for developing countries.

Ponce, Olivié and Onofa (2011) evaluate the impact of remittances on health outcomes in Ecuador, and they find that while remittances do have an impact on health expenditures, no significant effects on long-term child health variables were found. They concluded that remittances are used for both preventative and emergency health situations.

Ratha (2003) finds that for rural households, remittances lead to multiplier effects because they are more likely to be spent on domestically produced goods, which is more likely to help the economy since low-income households have a higher marginal propensity to consume. Giuliano and Ruiz-Arranz (2005) worked on a data set of more than 100 developing countries for the 1975-2002 period and found that remittances can enhance economic growth, but only in less financially developed countries. Finally, Nsiah and Fayissa (2015) use panel unit root 
and cointegration tests to investigate the relationship between economic growth and remittances for 64 African, Asian, and Latin American-Caribbean countries during 1987-2007. They found that remittances and economic growth have a positive relationship with each other.

However, some studies suggest that remittances may have a negative impact on economic growth. They increase recipients' wealth and can reduce incentives to work which can hamper economic growth. Amuedo-Dorantes and Pozo (2006) argue that remittances could undermine export sectors of the recipient countries, thereby reducing international competitiveness. Chami et al. (2003) showed that remittances had a negative effect on economic growth in 113 countries from 1970-1998, concluding that they serve as a type of compensation for countries with poor economic conditions. Some studies also suggest that the upward trend in remittances could be damaging to the long-run economic growth of recipient countries due to an appreciation of the real exchange rate. The inward flow of remittances can appreciate the exchange rate of recipient economies and therefore reduce the competitiveness of the export sector (Acosta et al., 2009).

Lastly, Chami and Jahjah (2005) found that growth in immigrants' remittances led to a negative growth in GDP per capita - they offer this result as a stylized fact which is to be investigated further. They also concluded that remittances appear to be intended as compensation for the country's poor economic performance and not as capital development.

One reason for these contradicting results and opinions may be the difficulty in identifying the direction of the relationship between remittances and economic growth. Furthermore, economic growth is inaccurate as a measure of well-being, since it does not consider human development indicators such as health and education (Anand and Sen, 2000). According to Meyer and Shera (2017), there has been little empirical work done to examine the relationship between remittances and human development in developing countries. Furthermore, for some of the above-mentioned studies, the endogeneity problem still exists.

\section{Empirical Model}

This paper seeks to examine the relationship between remittances, real GDP per capita, and the infant mortality rate in India during 1975-2018 (years 2019 and 2020 are not included due to a lack of data). It uses single break unit root test and Johansen cointegration analysis to determine whether there is a stable long-run relationship among the three variables, and then estimates a VECM which includes three dummy variables in order to examine the adjustment speed. The VECM model takes the general form of:

$$
\begin{aligned}
\Delta \log G D P_{1 t}=a_{10} & +\sum_{i=1}^{p} a_{11} \Delta \log G D P_{1, t-i}+\sum_{i=1}^{p} a_{12} \Delta \log I M R_{1, t-i}+\sum_{i=1}^{p} a_{13} \Delta \log R E M I T_{1, t-i} \\
& +a_{14} D 1+a_{15} D 2+a_{16} D 3+\lambda_{1} E C T_{t-1}+\mu_{1 t}
\end{aligned}
$$




$$
\begin{aligned}
\Delta \log I M R_{2 t}= & a_{20} \\
+ & \sum_{i=1}^{p} a_{21} \Delta \log G D P_{2, t-i}+\sum_{i=1}^{p} a_{22} \Delta \log I M R_{2, t-i}+\sum_{i=1}^{p} a_{23} \Delta \operatorname{Llog} R E M I T_{2, t-i} \\
& +a_{24} D 1+a_{25} D 2+a_{26} D 3+\lambda_{2} E C T_{t-1}+\mu_{2 t} \\
\operatorname{LlogREMIT}_{3 t}= & a_{30}+\sum_{i=1}^{p} a_{31} \Delta \log G D P_{3, t-i}+\sum_{i=1}^{p} a_{32} \Delta \log I M R_{3, t-i}+\sum_{i=1}^{p} a_{33} \Delta \operatorname{LlogREMIT} T_{3, t-i} \\
& +a_{34} D 1+a_{35} D 2+a_{36} D 3+\lambda_{3} E C T_{t-1}+\mu_{3 t}
\end{aligned}
$$

where $\log$ GDP refers to the log of the real GDP per capita (in constant 2010 US dollars), $\operatorname{logIMR}$ refers to the $\log$ of the infant mortality rate in India, and $\log$ REMIT refers to the $\log$ of personal remittances received by India in current U.S. dollars. Data for all three of the variables are taken from the World Bank database which is, in turn, obtained from the World Bank national accounts data, the OECD National Accounts data files, and the IMF balance of payments data.

\section{Data}

In a VEC model, all three variables are assumed to be endogenous. They are logarithmically transformed for the error correction model and for ease of interpretation. $\log$ GDP refers to the log of the real GDP per capita, which is measured by dividing the GDP by the population. Data for $\log$ GDP are in constant 2010 U.S. dollars. $\operatorname{logIMR}$ refers to the log of the infant mortality rate, which is defined as the number of infants dying before reaching one year of age, per 1,000 births in a year. $\operatorname{logREMIT}$ refers to the log of personal remittances received, and it comprises personal transfers and compensation of employees. Personal transfers consist of all current transfers between resident and non-resident individuals. Compensation of employees refers to the income of employers for work done in a given year. Data for logREMIT are in current U.S. dollars.

Dummy variables D1, D2 and D3 are used in the vector error correction model to incorporate the structural breaks found in the data. D1 accounts for the crisis years experienced by the Indian economy, including recessions, droughts, and oil crises which adversely impacted GDP. D2 accounts for the economic boom experienced during 2003-2007, also called India's Dream Run under Prime Ministers Atal Bihari Vajpayee and Manmohan Singh. D3 accounts for policies enacted by the Indian government that significantly affected both the inflow of remittances to India and the infant mortality rate, such as India's economic liberalization which started in 1991 and the subsequent introduction of the market exchange rate system which was enacted in 1993, and various reforms in the 1990s and into the 2000s that relaxed controls on foreign exchange transactions and helped contribute to the remittance surge seen in 2005-2006. It also includes policies such as the introduction of the "Cradle Babies" program in 1992 and the National Health Policy in 2002. 
The relationship between $\log$ REMIT and $\operatorname{logIMR}$ is expected to be negative because it is hypothesized that an increase in the inflow of personal remittances to India will decrease the infant mortality rate since households would be able to spend a greater amount on infant healthcare. Similarly, the relationship between $\log$ REMIT and $\log$ GDP is expected to be positive since remittances are assumed to positively affect real GDP per capita.

Dummy variable D1 is expected to have a negative impact on logGDP. It is expected to have a positive effect on logREMIT because during a recession and/or oil crisis that threatens the incomes of families in India, members of those families residing abroad are expected to send back more remittances as a form of compensation for poor economic conditions (Chami et al., 2003). D1 is also expected to have a positive effect on logIMR, since during a recession, drought, or an oil crisis it is expected that families will have less income to spend toward healthcare for infants, thus increasing the infant mortality rate.

Dummy variable D2 is expected to have a negative relationship with logIMR, since during a boom it is expected that families will have more income available to spend toward healthcare for infants. It is expected to have a positive relationship with $\log$ GDP, and, according to theory, it is expected to have a negative relationship with logREMIT, since during a boom individuals living abroad may decide to send less money in remittances if they determine their family back in India is faring relatively better.

Dummy variable D3 is expected to have a negative impact on logIMR, since it accounts for policies that help reduce the infant mortality rate, and it is expected to have a positive effect on logREMIT, since it accounts for policies that helped make remittances more accessible in India.

\section{Estimation Results}

\subsection{Testing for Stationarity}

It is critical to test for the existence of unit roots to avoid misspecification or the estimation of spurious regressions. In order to save space, selected series are first plotted in level form and first differences (both in logarithmic form) in order to provide preliminary insights before unit root tests are conducted. Then, the Augmented-Dickey Fuller (ADF), Kwiatkowski-PhillipsSchmidt-Shin (KPSS) Lagrange Multiplier, Phillips-Perron (PP), and Zivot-Andrews Single Break unit root tests are conducted to determine the order of integration of the three time series variables (shown in Table 1 below).

\subsubsection{Graphical Analysis}

The log of GDP per capita in level form and first difference is plotted in Figures 1 and 2 in the Appendix below. ${ }^{1}$ In level form, the graph of $\log$ GDP seems to be a random walk with a positive drift and no deterministic time trend component since deviations from the mean are not quickly eliminated, so the mean is not constant. Therefore, in level form, logGDP seems to be non-stationary. Plotting the series in differenced form renders it stationary as there is reversion back to the constant long-run mean. In the differenced form, there is a significant structural break from 1979-1980, and this is due to the 1979 Oil Crisis as well as a drought in 
1979 in India, both of which significantly negatively impacted the GDP per capita. Another structural break can be seen in 1991, during which India was going through an economic crisis that was the result of poor economic policies and trade deficits.

Turning to the graph of logIMR in level form (available upon request), it seems to be a random walk with a negative drift and no deterministic time trend component since deviations from the mean are not quickly eliminated. Therefore, in level form, logIMR seems to be non-stationary. Plotting the series in differenced form removes some of the non-stationarity as it seems that the series is following a pattern, moving back to its long-run mean. In level form, it can be noticed that the slope of the graph slightly increases starting from 1995-2000, and this is due to the Indian government's policies during that time that helped prevent infant mortality, including the 1997 Reproductive and Child Health $(\mathrm{RCH})$ program, the National Population Policy of 2000, and the National Health Policy of 2002.

Finally, the graph of $\operatorname{logREMIT}$ (available upon request) seems to be a random walk with positive drift and no deterministic time trend component since deviations from the mean are not quickly eliminated, so the mean is not constant. Therefore, in level form, logREMIT seems to be non-stationary. Plotting the series in differenced form renders the series stationary as the series reverts back to its long-run (constant) mean. In differenced form, it can be seen that there is a significant structural break from 1979-1980, and this is attributed to the Second Oil Crisis. Another structural break can be noticed during 1991-1993, and this is when the Indian government introduced reforms that also helped boost remittances, such as policies for economic liberalization in 1991 and the introduction of the market exchange rate system in 1993.

Table 1. Results of Unit Root and Stationarity Tests

\begin{tabular}{|c|c|c|c|c|}
\hline & \multicolumn{4}{|l|}{ Level data } \\
\hline & $\mathrm{ADF}$ & KPSS & PP & ZA \\
\hline $\log G D P$ & $-1.540(0.7997)$ & 0.223 & $-1.702(0.7332)$ & $-3.097(0.1922)$ \\
\hline $\operatorname{logIMR}$ & $3.067(1.0000)$ & 0.214 & $3.228(1.0000)$ & $-1.40(0.7331)$ \\
\hline \multirow[t]{6}{*}{$\operatorname{logREMIT}$} & $-2.348(0.4002)$ & 0.081 & $-2.722(0.2333)$ & $-3.28(0.0104)$ \\
\hline & \multicolumn{4}{|c|}{ ADF and PP test critical values: $-4.19(1 \%),-3.52(5 \%),-3.19(10 \%)$} \\
\hline & \multicolumn{4}{|c|}{ KPSS critical values: $0.216(1 \%), 0.146(5 \%), 0.119(10 \%)$} \\
\hline & \multicolumn{4}{|c|}{ Zivot-Andrews test critical values: $-5.57(1 \%),-5.08(5 \%),-4.82(10 \%)$} \\
\hline & \multicolumn{4}{|c|}{ (p-values in parentheses) } \\
\hline & \multicolumn{4}{|c|}{ significance of $5 \%$ unless otherwise stated: $* 1 \%, * * 10 \%$} \\
\hline
\end{tabular}




\section{Macrothink}

\begin{tabular}{lllll}
\hline \multicolumn{5}{l}{ First differenced data } \\
\cline { 2 - 5 } & ADF & KPSS & PP & ZA \\
\hline $\log$ GDP & $-5.825(0.000)$ & 0.794 & $-15.541(0.0000)$ & -7.186 \\
$\operatorname{logIMR}$ & $0.641(0.9888)$ & 0.723 & $-2.692(0.0839)^{* *}$ & $-6.537(1 \mathrm{lag})$ \\
$\operatorname{logREMIT}$ & $-6.817(0.0000)$ & 0.144 & $-6.845(0.0000)$ & $-5.176(1 \mathrm{lag})^{*}$ \\
& ADF critical values: $-3.60(1 \%),-2.95(5 \%),-2.60(10 \%)$ & \\
& KPSS critical values: 0.739 $(1 \%), 0.463(5 \%), 0.347(10 \%)$ \\
& PP test critical values: $-4.19(1 \%),-3.52(5 \%),-3.19(10 \%)$ \\
& Zivot-Andrews test critical values: $-5.57(1 \%),-5.08(5 \%),-4.82(10 \%)$ \\
& (p-values in parentheses) & \\
& significance of 5\% unless otherwise stated: * $1 \%, * * 10 \%$ & \\
\hline
\end{tabular}

\subsubsection{Augmented-Dickey Fuller (ADF) Test}

ADF tests, shown in Table 1, are conducted for all three series in order to formally identify a unit root in the variables and to determine their order of integration. ADF tests have a lowpower and their power is further compromised if there are structural breaks in the series. The tests are conducted following the Dolado-Sosvilla-Rivero methodology, which suggests an initial test, the most unrestricted one, including both a trend and intercept and subsequent tests eliminating insignificant exogenous regressors.

For $\log \mathrm{GDP}$ in level form with both a constant and trend, the ADF t-statistic has a p-value of 0.7997, therefore the null hypothesis of a unit root in the level form cannot be rejected. Therefore, according to the ADF test, the series is non-stationary in level form. The ADF test is conducted on the first difference of $\log$ GDP, this time with a constant only, and the p-value of 0.0000 suggests that $\log$ GDP is stationary in first difference. Therefore, the ADF test suggests that $\log$ GDP is $\mathrm{I}(1)$.

Turning to logIMR in level form in its most unrestricted form, the ADF t-statistic has a p-value of 1.0000 , so the null hypothesis of a unit root in level form cannot be rejected. Thus, the series is non-stationary. The ADF test is then conducted in first difference with a constant only, and the p-value of 0.9888 suggests that logIMR is still non-stationary in first difference. However, it is critical to remember here that the ADF test is a low-power test and the existence of structural breaks further decreases its power-therefore, this result will be compared later against the KPSS (which is used to confirm the ADF test result) and the PP tests (which is a much more powerful test than the ADF).

Lastly, $\log$ REMIT is tested in its most unrestricted form and the ADF t-statistic has a p-value of 0.4002 , therefore the null hypothesis of a unit root in level form cannot be rejected and the series is non-stationary in level form. The ADF test is then conducted in first difference, this time with a constant only, and the p-value of 0.0000 suggests that $\log$ REMIT is stationary in first difference. Therefore, the ADF test suggests that logREMIT is I(1). 
5.1.3 Kwiatkowski-Phillips-Schmidt-Shin (KPSS) Lagrange Multiplier Test

The KPSS test, shown in Table 1, is a more powerful Lagrange Multiplier test designed to confirm the ADF test results, and its null and alternative hypotheses are reversed. Therefore, if the null is rejected, then the KPSS test suggests that the series in question exhibits a unit root.

For $\log$ GDP in level form, the KPSS statistic is 0.223 , which is greater than the $5 \%$ critical value of 0.146 ; thus, the null hypothesis of stationarity is rejected and the KPSS test confirms the findings of the ADF test of logGDP being I(1) in nature.

Turning to $\log I M R$ in level form, the KPSS statistic is 0.214 , which is greater than the $5 \%$ critical value of 0.146 ; therefore, the null hypothesis of stationarity is rejected at the $5 \%$ level of significance, and so according to the KPSS test $\operatorname{logIMR}$ is non-stationary in level form. In first difference, the KPSS statistic is 0.723 , which is greater than the $5 \%$ critical value of 0.463 ; therefore, in first difference the null of stationarity is rejected, and so the KPSS test confirms the ADF test result of logIMR being non-stationary in first difference as well.

The KPSS statistic is 0.081 for $\operatorname{logREMIT}$ in level form, which is less than the $5 \%$ critical value of 0.146 ; therefore, the null hypothesis of stationarity cannot be rejected for logREMIT, and so according to the KPSS test logREMIT is stationary in level form. This result contradicts that of the ADF test. Therefore, it will be compared later against the more powerful PP test.

\subsubsection{Phillips-Perron (PP) Test}

The PP t-statistic for logGDP in level form has a p-value of 0.7332 , therefore the null of nonstationarity cannot be rejected at the $5 \%$ level of significance, and it is concluded that logGDP is non-stationary. The PP test is then conducted on logGDP in first difference, this time with a constant only, and the p-value of 0.0000 suggests that logGDP is stationary in first difference. Therefore, the PP test suggests that $\log G D P$ is I(1) in nature.

For $\log I M R$ in level form, the PP t-statistic has a p-value of 1.0000 , therefore the null of nonstationarity cannot be rejected at the $5 \%$ level of significance, and it is concluded that logIMR is non-stationary in level form. The PP test is then conducted on logIMR in first difference, this time with a constant only, and since the p-value is 0.0839 , the null is of non-stationarity is rejected, which suggests that logIMR is stationary in first difference but only at a $10 \%$ level of significance. This result is important because it helps establish the I(1) nature for all three variables, and it is important that the order of integration of all three variables be the same in order to continue with cointegration analysis.

Lastly, the PP t-statistic for logREMIT in level form has a p-value of 0.2333 , thus the null of non-stationarity cannot be rejected at the $5 \%$ level of significance, and it is concluded that $\operatorname{logREMIT}$ is non-stationary. The PP test is then conducted on logGDP first difference, this time with a constant only, and the p-value of 0.0000 suggests that logREMIT is stationary in first difference. Therefore, the PP test suggests that logREMIT is I(1).

According to the PP test, which is more powerful than the ADF test, it is concluded that all three series are integrated of order 1 , that is, (logGDP, $\log I M R, \operatorname{logREMIT}) \sim \mathrm{I}(1)$. 


\subsubsection{Zivot-Andrews Single Break Unit Root Test}

The Zivot-Andrews Single Break unit root test is used to detect unit roots when there is a single structural break in the series. Standard unit root tests have relatively low power if the presence of a structural break is ignored and are thus more likely to conclude that the series is nonstationary when in fact it does not have a unit root. Furthermore, it is important to keep in mind that the Zivot-Andrews test only finds a single structural break even though there might be multiple breaks in the series; therefore, its power is compromised in the presence of multiple breaks. Three models, Model A, B, and C, can be selected while conducting the Zivot-Andrews test; however, according to Seton (2003), Model C is preferred at all times because the test loses minimal power if the structural break date is correctly characterized by Model A but researchers incorrectly use Model $\mathrm{C}$, but the loss in power is significant if the correct model was Model $\mathrm{C}$ and researchers assume that the structural break occurred according to Model $\mathrm{A}$. Therefore, for the Zivot-Andrews test on all three variables, only Model C is used and reported. The null hypothesis of non-stationarity with a structural break in both the intercept and the trend (characterized by Model C) is rejected if the Zivot-Andrews t-statistic is greater than the critical value in absolute terms. For the Zivot-Andrews test, the p-value is ignored because it does not take into account the existence of structural breaks. Since the series are annual data, the lags selected are 1-2 lags for all three of the variables.

For $\log$ GDP in level form, the Zivot-Andrews t-statistic is -3.097 , which is less than the 5\% critical value of -5.08 in absolute terms. The test found a structural break in 2003, which is when the Resurgent India Bonds, which were launched in 1998, matured. A significant amount of these bonds were retained in India instead of being sent abroad in foreign currency, which resulted in the bulge in GDP in 2003-2004. Furthermore, in 2003, the Indian economy was also going through a boom. The null hypothesis of non-stationarity with a structural break thus cannot be rejected for 2 lags. Therefore, according to the Zivot-Andrews test, logGDP is nonstationary in level form with a structural break. For logGDP in first differenced form, the ZivotAndrews t-statistic is -7.186 , which is greater than the $5 \%$ critical value of -5.08 in absolute terms. The test found a structural break in 1991, which is supported by real world events - in 1991, India was going through an economic crisis that was the result of poor economic policies and trade deficits. The null hypothesis of non-stationarity with a structural break is thus rejected for 2 lags. Therefore, according to the Zivot-Andrews test, logGDP is stationary at the level form with a structural break.

Turning to $\operatorname{logIMR}$ in level form, the Zivot-Andrews t-statistic is -1.400 , which is less than the $5 \%$ critical value of -5.08 in absolute terms. The test found a structural break in 2002, which is when the National Health Policy was introduced. Also in 2002, India was hit by a severe drought which might have also caused a bump in remittances from non-resident Indians living abroad. The null hypothesis of non-stationarity with a structural break thus cannot be rejected for 2 lags. Therefore, according to the Zivot-Andrews test, $\operatorname{logIMR}$ is non-stationary in level form with a structural break. For $\log I M R$ in first difference form, the Zivot-Andrews t-statistic is -6.537 , which is larger than the $5 \%$ critical value of -5.08 in absolute terms ( $1 \mathrm{lag})$. The test found a structural break in 1998, which may have captured the effect of the introduction of the Reproductive and Child Health ( $\mathrm{RCH})$ program in 1997. The null hypothesis of non- 
stationarity with a structural break is thus rejected for 1 lag only. Thus, according to the ZivotAndrews test, $\operatorname{logIMR}$ is stationary in first difference form with a structural break.

The Zivot-Andrews t-statistic is -3.284 for $\operatorname{logREMIT}$ in level form, which is less than the 5\% critical value of -5.08 in absolute terms. The test found a structural break in 1994, which was marked by the migration of information technology (IT) workers from India, principally to the United States, who started sending remittances back home. The null hypothesis of nonstationarity with a structural break thus cannot be rejected for 2 lags. Therefore, according to the Zivot-Andrews test, logIMR is non-stationary in level form with a structural break. For $\operatorname{logIMR}$ in first differences, the Zivot-Andrews t-statistic is -5.176 , which is greater than the $5 \%$ critical value of -5.08 in absolute terms (1 lag). The test found a structural break in 1991, which marked the economic liberalization of India, including policies that helped make it easier to send and receive remittances back home. The null hypothesis of non-stationarity with a structural break is thus rejected for 1 lag only. Therefore, according to the Zivot-Andrews test, $\operatorname{logREMIT}$ is stationary in first difference form with a structural break.

In view of all of the tests undertaken above, it is concluded that all three variables are integrated of order one.

\subsection{Cointegration Analysis}

Since all three variables are integrated of the same order, I(1), cointegration analysis can now be undertaken. There are two procedures for cointegration; the Engle-Granger procedure is used when there are only two variables, and it finds the presence of one cointegrating relationship between the two variables. The Johansen-Juselius (1990) multivariate cointegration procedure is used when there are more than two variables. It determines whether there is a stable, long-run I(0) relationship present among the three I(1) series, and since it is a one-step process (as opposed to the two-step E-G procedure) there is less room for errors.

\subsubsection{Johansen Procedure}

Before running the Johansen test, the Pantula Principle (shown in Table 2) is employed in order to select the appropriate specification of the model in terms of the deterministic components, trend and the intercept. There are 5 models to choose from, but Models 1 and 5 are deemed to be implausible from an econometric standpoint. Therefore, only Models 2, 3, and 4 are used in the selection procedure. Model 2 is the most restrictive model, and includes an intercept but no trend in the cointegrating equation, and no intercept or trend in the VAR model (the short-run, differenced model). It assumes that there is no deterministic trend in the data. Model 3 is a less restrictive model, and it includes an intercept but no trend for both the cointegrating equation and the VAR model (the short-run, differenced model). It allows for a linear deterministic trend in the data. Model 4, which is the least restrictive model, includes an intercept for both the cointegrating equation and the VAR model, and a trend for the cointegrating equation but no trend for the VAR model. It allows for a linear deterministic trend in the data. According to the Pantula Principle, model selection must go from the most restrictive to the least restrictive model (that is, from Model 2 to 4). It compares the models' trace statistics to their critical values, and stops when the null hypothesis of no cointegration cannot be rejected for the first time. 
The Johansen cointegration test is run for the three variables logGDP, logIMR, and logREMIT as well as the three dummy variables (for Models 2, 3, and 4), for up to 2 lags. Therefore, based on the Pantula selection procedure, at the $5 \%$ significance level, there is 1 cointegrating vector and Model 4 should be chosen because it is the last significant estimate before the null hypothesis of no cointegration cannot be rejected at the 5\% level. Results are shown in Table 2.

\subsubsection{Vector Error Correction Model (VECM) Results and Analysis}

Since the Johansen procedure finds one cointegrating vector, suggesting the existence of a longrun stable relationship among the variables, a VECM is estimated for the three endogenous variables $\log$ GDP, $\log$ IMR, and $\operatorname{logREMIT}$, as well as for the three exogenous dummy variables D1, D2, and D3, for two lags. The VECM is estimated using only 1 cointegrating vector because the imposition of zero restrictions on the adjustment coefficients of each equation (discussed below) suggests that the cointegrating vector should be normalized on logIMR, thus treating it as the "dependent" variable in the model, while treating logGDP and logREMIT as weakly exogenous. Results are reported in Table 3.

Table 2. Pantula Selection Procedure

\begin{tabular}{lllll}
\hline $\begin{array}{l}\text { r (number of } \\
\text { cointegrating } \\
\text { vectors) }\end{array}$ & $\begin{array}{l}\text { n-r (number of variables } \\
\text { minus number of } \\
\text { cointegrating vector) }\end{array}$ & Model 2 & Model 3 & Model 4 \\
\hline Up to 0 & 3 & 51.98178 reject & 50.34498 reject & 59.74850 reject \\
Up to 1 & 2 & $15.95915^{*}$ fail & 14.33283 fail & 18.47980 fail \\
Up to 2 & 1 & 3.121973 fail & 1.929782 fail & 4.364333 fail \\
\hline
\end{tabular}

Model 2: Trace test indicates 1 cointegrating eqn(s) at the 0.05 level

Model 3: Trace test indicates 1 cointegrating eqn(s) at the 0.05 level

Model 4: Trace test indicates 1 cointegrating eqn(s) at the 0.05 level

* denotes the last significant estimate before the null of no cointegration cannot be rejected at the $5 \%$ level

Results for the variables in the long-run are as hypothesized. For instance, a one percent increase in remittances decreases the infant mortality rate by $0.13 \%$, all else held constant. Also, in the long run, a one percent increase in the real GDP per capita decreases the infant mortality rate by $1.83 \%$, all else held constant. These results are significant at the $5 \%$ level threshold, and they make theoretical and economic sense. Furthermore, these results are supported by the literature, because an increase in remittances leads to an increase in infant healthcare expenditure which reduces the infant mortality rate (Azizi, 2018). An increase in per capita GDP also decreases the infant mortality rate since families now have more in income to spend towards infant healthcare.

The VECM finds a negative and a highly significant adjustment coefficient for one of the three 
equations: $\mathrm{D}(\log I M R)$; that is, the null hypothesis that the adjustment coefficient is zero can be rejected at the $5 \%$ level of significance. This means that for this system of equations there is a short-run adjustment mechanism based on the $\bar{R}^{2}$ and the AIC/SBC criteria. The VECM results indicate that the $\mathrm{D}(\log I M R)$ equation is the best one out of all three equations. This is because it is the only equation that has the correct sign (negative and highly significant) on the error correction term as the theory predicts, has the lowest SBC and AIC, the highest $R^{2}$, and the highest F-statistic. According to the $\bar{R}^{2}, 80.86 \%$ of the variance in logIMR is explained by lagged values in its own variance, as well as those of $\operatorname{logREMIT}$ and $\log$ GDP; therefore, this is a good model. The negative and a highly significant adjustment coefficient implies that a ten percent deviation away from equilibrium during the current year is corrected in the next year by $0.70 \%$.

Table 3. VECM Output

Included observations: 41 after adjustments

Standard errors in ( ) \& t-statistics in [ ]

\begin{tabular}{|c|c|c|c|}
\hline Cointegrating Eq: & & \multicolumn{2}{|l|}{ CointEq1 } \\
\hline LOGIMR(-1) & & 1.000000 & \\
\hline \multirow[t]{3}{*}{ LOGGDP(-1) } & & 1.833762 & \\
\hline & & $(0.27431)$ & \\
\hline & & [ 6.68494] & \\
\hline \multirow[t]{3}{*}{ LOGREMIT(-1) } & & 0.132326 & \\
\hline & & $(0.04791)$ & \\
\hline & & {$[2.76192]$} & \\
\hline \multirow[t]{3}{*}{ @TREND(75) } & & -0.029344 & \\
\hline & & $(0.01070)$ & \\
\hline & & {$[-2.74179]$} & \\
\hline $\mathrm{C}$ & & -16.98966 & \\
\hline Error Correction: & D(LOGIMR) & D(LOGGDP) & D(LOGREMIT) \\
\hline \multirow[t]{3}{*}{ CointEq1 } & -0.070315 & 0.059033 & 0.106645 \\
\hline & $(0.01077)$ & $(0.04635)$ & $(0.33886)$ \\
\hline & {$[-6.52884]$} & {$[1.27360]$} & {$[0.31472]$} \\
\hline \multirow[t]{3}{*}{ D(LOGIMR(-1)) } & -0.670033 & 0.044069 & 5.985889 \\
\hline & $(0.15363)$ & $(0.66117)$ & $(4.83356)$ \\
\hline & {$[-4.36148]$} & {$[0.06665]$} & {$[1.23840]$} \\
\hline \multirow[t]{3}{*}{ D(LOGIMR(-2)) } & -0.393229 & 0.310898 & -2.070684 \\
\hline & $(0.19800)$ & $(0.85213)$ & $(6.22963)$ \\
\hline & {$[-1.98603]$} & {$[0.36485]$} & {$[-0.33239]$} \\
\hline \multirow[t]{3}{*}{ D(LOGGDP(-1)) } & 0.122134 & -0.380501 & -1.735981 \\
\hline & $(0.04788)$ & $(0.20608)$ & $(1.50660)$ \\
\hline & {$[2.55060]$} & {$[-1.84634]$} & {$[-1.15225]$} \\
\hline
\end{tabular}


D(LOGGDP(-2))

0.098652

(0.04531)

[2.17740]

$\begin{array}{rr}\text { D(LOGREMIT(-1)) } & 0.010725 \\ & (0.00612) \\ & {[1.75199]}\end{array}$

D(LOGREMIT(-2))

0.002919

$(0.00483)$

[ 0.60433]

C

$$
\begin{array}{r}
-0.080829 \\
(0.01310) \\
{[-6.17226]}
\end{array}
$$

BOOM

0.003661

(0.00272)

[ 1.34853]

CRISIS

$$
\begin{array}{r}
-0.003864 \\
(0.00217) \\
{[-1.77731]}
\end{array}
$$

$$
-0.018885
$$$$
\text { (0.02079) }
$$

[-0.90835]

0.085072

(0.05636)

[ 1.50943 ]

0.014848

(0.01169)

[ 1.27067$]$

$-0.030367$

(0.00936)

[-3.24544]

0.283082

(0.15199)

[ 1.86246]

0.161338

(0.41203)

[ 0.39157]

$-0.000765$

(0.08543)

[-0.00896]

0.080399

(0.06841)

[ 1.17534]

COMBPOL

$$
0.001958
$$

(0.00217)

$-0.003078$

(0.00935)

0.130286

[0.90134]

R-squared

0.856491

Adj. R-squared

0.808654

Sum sq. resids

0.000788

0.005124

[-0.32927]

0.486477

(0.06834)

[ 1.90652]

0.382676

S.E. equation

17.90456

164.4555

Log likelihood

$-7.485635$

0.315303

0.176902

0.014588

0.779671

0.022052

0.161211

2.841998

1.859687

104.6165

23.05385

Akaike AIC

$-7.025896$

$-4.566658$

$-0.587993$

Schwarz SC

$-0.034808$

$-4.106919$

$-0.128254$

0.038880

0.106676

0.011713

S.D. dependent

0.026650

0.177693

Determinant resid covariance (dof adj.)

$2.80 \mathrm{E}-10$

Determinant resid covariance

$1.10 \mathrm{E}-10$

Log likelihood

295.5679

Akaike information criterion

$-12.61307$

Schwarz criterion

$-11.06667$

Number of coefficients 37 
The VECM framework enables researchers to determine which variables are weakly exogenous by imposing zero coefficients on the adjustment coefficients of each equation. Based on this weak exogeneity test (likelihood ratio test), the $\operatorname{logREMIT}$ and $\log$ GDP variables can be omitted from the system (treated as weakly exogenous) because the null hypothesis of a zero restriction is not rejected for these variables at the 5\% level. The p-values for the included variables are, respectively, for $\log I M R, \operatorname{logREMIT}$, and $\log$ GDP as follows: $0.000,0.188$, and 0.730. In other words, in this simple three equation system, $\operatorname{logIMR}$ can be treated as endogenous, while logREMIT and $\log$ GDP are determined from outside the system (exogenous).

For $\mathrm{D}(\operatorname{logIMR})$ (equation 1$)$, the VECM states that in the short-run, a percentage increase in $\log$ GDP and $\operatorname{logREMIT}$ in the previous year increases the infant mortality rate by 0.12 and $0.01 \%$, respectively, all else held constant; these results are significant and not in line with the long-run results reported in the cointegrating vector. Given that these are short-run impact multipliers, it may be the case that not enough time has elapsed for the full effect of changes in GDP and remittances to be captured by infant mortality rates. In the short run, a percentage increase in $\operatorname{logIMR}$ in the current year decreases the infant mortality rate by about $0.67 \%$ next year, all else held constant; this result could be interpreted more as a correlation than a causation - the infant mortality rate in India has been decreasing since the 1970s; however, it could also be attributed to the Indian government's policies to prevent infant mortality around the country. This relationship is significant. Only dummy variable D1 is significant - according to the results, a crisis year decreases the infant mortality rate by $0.004 \%$; this is a slightly significant effect so it cannot be ignored; however, the result could be attributed to correlation rather than causation, because India has consistently seen a downward trend in the infant mortality rate. Dummy variables D2 and D3 are insignificant in explaining the variation in $\operatorname{logIMR.}$

For $\mathrm{D}(\log \mathrm{GDP})$ (equation 2), the VECM states that in the short-run, a percentage increase in $\operatorname{logIMR}$ in the previous period decreases the real GDP per capita in the current year by $0.44 \%$. This is not unexpected because as infant mortality increases, the real GDP per capita might go down in the next year as a household deals with the loss-however, this is an insignificant result and could be attributed to correlation rather than causation. In the short-run, a percentage increase in remittances in the previous period decreases the real GDP per capita in the current year by $0.01 \%$, this unexpected result may be due to the fact that remittances are expected to have a positive impact on economic growth in the long run for developing countries (Azam, 2015, Jouini, 2015, Kumar, 2013); also, it is an insignificant result. For this equation, the only significant dummy variable is D1, which accounts for crisis years, and the results indicate that during a crisis year the real GDP per capita goes down by $0.03 \%$, which is expected because during recessions or droughts the GDP of a country goes down. The coefficient on the error correction term has a positive sign but it is insignificant; therefore, for this equation there is no adjustment in the current period from any disequilibrium in the previous period. LogGDP is weakly exogenous and therefore it can be omitted from the system.

For $\mathrm{D}(\operatorname{logREMIT})$ (equation 3), the VECM states that in the short-run, a percentage increase in the infant mortality rate in the previous year will increase remittances by $5.99 \%$ in the current 
year - this is expected because, on average, an increase in infant mortality might encourage non-resident Indians living abroad to send greater remittances back home in order to help support their family. However, this is an insignificant result. In the short-run, a percentage increase in the real GDP per capita in the previous year will decrease remittances in the current year by $1.74 \%$ - this is again an expected result because as the GDP in India rises, non-resident Indians living abroad might decide to lower the amount of remittances they send back home since the economy has improved since last year, and so the household might not be in too much need of remittances this year; however, this result is also insignificant in the short run. For this equation, none of the dummy variables are significant; the only dummy that is close to some significance (at a 20\% level) is D3, which accounts for policies that were implemented to help improve remittances and lower the infant mortality rate, which shows that an implementation of a policy in the last year leads to an increase in the remittances in the current year by $0.13 \%$. The coefficient on the error correction term has a positive sign and is insignificant; therefore, for this equation there is no adjustment in the current period from any disequilibrium in the previous period. LogREMIT is weakly exogenous and can thus be omitted from the system.

\section{Causality Tests}

To further investigate the "causal" relationship among the three variables, a Granger Causality/Block Exogeneity test is performed. This test examines all three equations, and the results are reported in Table 1. Pairwise Granger Causality tests are also conducted in order to look at all three of the variables as pairs of two and with more than $1 \mathrm{lag}$, and the results are reported in Table 2. Lastly, impulse response functions are also graphed and are shown in Figure 7.

\subsection{Granger Causality/Block Exogeneity Tests}

A Granger Causality test can only be conducted if there is stationarity and cointegration among all the three variables. Since the Johansen test established cointegration, the Granger Causality test can thus be conducted. The results are reported in Table 4.

The Granger test indicates that real GDP per capita "Granger causes" the infant mortality rate at a $5 \%$ level of significance, while remittances do not "Granger cause" the infant mortality rate. As a group, both the real GDP per capita and remittances "Granger cause" the infant mortality rate at a $10 \%$ level of significance. This is an expected result because, according to literature, both real GDP per capita and remittances are expected to "cause" the infant mortality rate; that is, if the real GDP per capita or remittances go up, then the infant mortality rate should go down (Azizi, 2018). The Granger test result also indicates that infant mortality rate and remittances do not "Granger cause" logGDP (either separately or as a group), which is an unexpected result because studies show that remittances have a positive impact on GDP in developing countries (Azam, 2015; Jouini, 2015; Kumar, 2013). Lastly, according to the Granger test, the real GDP per capita "Granger causes" remittances at a $10 \%$ level, while the infant mortality rate does not. As a group, the variables only "Granger cause" remittances at a $12 \%$ level of significance. This is consistent with the result from equation 3 , which indicates 
that as the GDP in India rises, non-resident Indians living abroad might decide to lower the amount of remittances they send back home since the economy has improved since last year, and so the household might not be in too much need of remittances in the current year. Also, an increase in the infant mortality might also encourage non-resident Indians living abroad to send greater remittances back home in order to help support their family. Thus, these Granger results make sense and are somewhat consistent with the VECM results.

The unexpected results generated for the Granger Block Causality test could be attributed to the fact that the test was only run for 2 lags (short-run effect), while the effect or "Granger causality" on the variables might be felt after more than 2 lags (in the long run). Therefore, in order to minimize the loss in degrees of freedom associated with using the Granger Block test, Pairwise Granger Causality tests are run in order to account for multiple lags.

Table 4. Granger Causality Tests

VEC Granger Causality/Block Exogeneity Wald Tests

Sample: 19752018

Included observations: 41

\begin{tabular}{lclc}
\hline Dependent variable: D(LOGIMR) & & \\
\hline Excluded & Chi-sq & df & Prob. \\
\hline D(LOGGDP) & 7.835922 & 2 & 0.0199 \\
D(LOGREMIT) & 3.086614 & 2 & 0.2137 \\
All & 7.886402 & 4 & 0.0958 \\
\hline
\end{tabular}

Dependent variable: D(LOGGDP)

\begin{tabular}{llll}
\hline Excluded & Chi-sq & df & Prob. \\
\hline D(LOGIMR) & 0.141748 & 2 & 0.9316 \\
D(LOGREMIT) & 0.858160 & 2 & 0.6511 \\
All & 0.878513 & 4 & 0.9276
\end{tabular}

Dependent variable: D(LOGREMIT)

\begin{tabular}{llll}
\hline Excluded & Chi-sq & df & Prob. \\
\hline D(LOGIMR) & 2.397116 & 2 & 0.3016 \\
D(LOGGDP) & 4.896231 & 2 & 0.0865 \\
All & 7.324740 & 4 & 0.1197 \\
\hline
\end{tabular}

\subsection{Pairwise Granger Causality Tests}

Pairwise Granger Causality tests are run in order to account for more than 2 lags, since the results are sensitive to the number of lags used. The tests are run for 3 lags, and results are reported in Table 5.

At 1 lag, the real GDP per capita "Granger causes" the infant mortality rate and remittances (separately) at a 5\% level of significance, remittances "Granger cause" the real GDP per capita, but only at a $10 \%$ level of significance, and the infant mortality rate "Granger causes" the real 
GDP per capita at a 5\% level of significance.

At 2 lags, both real GDP per capita and the infant mortality rate "Granger cause" each other at a 5\% level of significance, and real GDP per capita "Granger causes" remittances at a 10\% level.

At 3 lags, both real GDP per capita and the infant mortality rate "Granger cause" each other at a 5\% level of significance, and real GDP per capita "Granger causes" remittances at a 10\% level.

From the Granger Causality tests, it can be concluded that real GDP per capita and the infant mortality rate both exhibit bi-directional "causality" (that is, they both cause each other), while real GDP per capita also "causes" remittances. These results are consistent with results from similar studies.

Table 5. Pairwise Granger Causality Tests

Pairwise Granger Causality Tests

Sample: 19752018

Lags: 1

\begin{tabular}{lccl}
\hline Null Hypothesis: & Obs & F-Statistic & Prob. \\
\hline LOGIMR does not Granger Cause LOGGDP & 43 & 9.13178 & 0.0044 \\
LOGGDP does not Granger Cause LOGIMR & & 6.64769 & 0.0137 \\
LOGREMIT does not Granger Cause LOGGDP & 43 & 2.79134 & 0.1026 \\
LOGGDP does not Granger Cause LOGREMIT & & 4.49415 & 0.0403 \\
LOGREMIT does not Granger Cause LOGIMR & 43 & 0.79404 & 0.3782 \\
LOGIMR does not Granger Cause LOGREMIT & & 2.15072 & 0.1503 \\
\hline Lags: 2 & & & \\
\hline Null Hypothesis: & Obs & F-Statistic & Prob. \\
\hline LOGIMR does not Granger Cause LOGGDP & 42 & 3.11699 & 0.0561 \\
LOGGDP does not Granger Cause LOGIMR & & 5.80270 & 0.0064 \\
LOGREMIT does not Granger Cause LOGGDP & 42 & 0.72882 & 0.4893 \\
LOGGDP does not Granger Cause LOGREMIT & & 3.02598 & 0.0607 \\
LOGREMIT does not Granger Cause LOGIMR & 42 & 1.25691 & 0.2964 \\
LOGIMR does not Granger Cause LOGREMIT & & 0.82654 & 0.4455 \\
\hline Lags: 3 & & & \\
\hline Null Hypothesis: & Obs & F-Statistic & Prob. \\
\hline LOGIMR does not Granger Cause LOGGDP & 41 & 3.05185 & 0.0416 \\
LOGGDP does not Granger Cause LOGIMR & \multirow{2}{*}{41} & 4.55576 & 0.0087 \\
LOGREMIT does not Granger Cause LOGGDP & & 2.47230 & 0.2394 \\
LOGGDP does not Granger Cause LOGREMIT & \multirow{2}{*}{41} & 1.39835 & 0.0506 \\
LOGREMIT does not Granger Cause LOGIMR & & 0.99945 & 0.4601 \\
LOGIMR does not Granger Cause LOGREMIT & &
\end{tabular}




\subsection{Impulse Response Functions}

Impulse response functions are used to analyze how the model responds to certain (unit) shocks to each of the variables in the model. Results for 10 periods are obtained, and are shown in Figure 3 in the Appendix below.

The impulse response graphs show that a positive unit shock to logGDP leads to a decrease in $\operatorname{logIMR}$ after two periods, which is an expected result; similarly, a positive unit shock to remittances generates an expected decrease in $\operatorname{logIMR}$ after two periods. That is, an increase in remittances as well as an increase in GDP lead to lagged decreases in the infant mortality rate, which are both expected results backed by existing literature A positive unit shock to $\operatorname{logIMR}$ increases the remittances for the first couple periods, after which there is largely no impact on remittances of an increase in $\operatorname{logIMR}$. A positive unit shock to remittances increases $\log$ GDP after three periods, which is an expected result; and finally, a positive unit shock to remittances decreases GDP at first and then increases it during the second and third period, after which there is no effect.

\section{Summary and Conclusion}

This paper examined the relationship between the real GDP per capita, remittances, and the infant mortality rate in India during the 1975-2018 period by employing the Johansen cointegration procedure and estimating a VECM. Results show that there exists a long-run equilibrium relationship between logIMR and its determinants, logGDP and logREMIT. In the long run, both remittances and real GDP per capita have a negative and significant impact on infant mortality rates in India. This is also confirmed by the impulse response functions. Treating infant mortality rate as a dependent variable is warranted by weak exogeneity tests and the sign of the cointegrating vector is negative and significant as the theory predicts. Real GDP per capita and the infant mortality rate both "cause" each other, while real GDP per capita also "causes" remittances. These results are consistent with studies conducted by Azizi (2018) and Azam (2015), Jouini (2015), and Kumar (2013). During crisis years, real GDP per capita goes down; therefore, remittances are used as compensation for lower GDP (Chami et al., 2003). Based on these results, the Indian government should strive to improve the financial system in India and further introduce policies that encourage remittances from abroad in order to lower the infant mortality rate.

\section{References}

Acosta, P. A., Lartey, E. K., \& Mandelman, F. (2009). Remittances and the Dutch Disease. SSRN Electronic Journal. https://doi.org/10.2139/ssrn.985907

Adams, R. H., \& Cuecuecha, A. (2013). The impact of remittances on investment and poverty in Ghana. World Development, 50, 24-40. https://doi.org/10.1016/j.worlddev.2013.04.009 
Airola, J. (2007). The use of remittance income in Mexico. International Migration Review, 41(4), 850-859. https://doi.org/10.1111/j.1747-7379.2007.00111.x

Amuedo-Dorantes, C., \& Pozo, S. (2006). Remittances as insurance: evidence from Mexican immigrants. Journal of Population Economics, 19(2), 227-254. https://doi.org/10.1007/s00148-006-0079-6

Chami, R., Barajas, A., Montiel, P., \& Hakura, D. (2010). Workers' remittances and the equilibrium real exchange rate: Theory and evidence. IMF Working Papers, 10(287), 1. https://doi.org/10.5089/9781455210947.001

Chami, R., Ernst, E., Fullenkamp, C., \& Oeking, A. (2018). Are remittances good for labor markets in LICs, MICs and fragile states? IMF Working Papers, 18(102), 1. https://doi.org/10.5089/9781484353615.001

de Haas, H. (2009). Remittances and social development. In: Hujo K., McClanahan S. (Eds.), Financing Social Policy. Social Policy in a Development Context. Palgrave Macmillan, London. https://doi.org/10.1057/9780230244337_12

Hall, G., \& Patrinos, H. A. (2004). Indigenous peoples, poverty and human development in Latin America. https://doi.org/10.1596/978-1-4039-9938-2

Johansen, S., \& Juselius, K. (1990). Maximum likelihood estimation and inference on cointegration - with applications to the demand for money. Oxford Bulletin of Economics and Statistics, 52(2), 169-210. https://doi.org/10.1111/j.1468-0084.1990.mp52002003.x

Jouini, J. (2015). Economic growth and remittances in Tunisia: Bi-directional causal links. Journal of Policy Modeling, 37(2), 355-373. https://doi.org/10.1016/j.jpolmod.2015.01.015

Kumar, R. R. (2013). Remittances and economic growth: A study of Guyana. Economic Systems, 37(3), 462-472. https://doi.org/10.1016/j.ecosys.2013.01.001

Mundaca, B. G. (2009). Remittances, financial market development, and economic growth: The case of Latin America and the Caribbean. Review of Development Economics, 13(2), 288-303. https://doi.org/10.1111/j.1467-9361.2008.00487.x

O'Hare, B., Makuta, I., Chiwaula, L., \& Bar-Zeev, N. (2013). Income and child mortality in developing countries: a systematic review and meta-analysis. Journal of the Royal Society of Medicine, 106(10), 408-414. https://doi.org/10.1177/0141076813489680

Ramirez, M.D. (2013). Do financial and institutional variables enhance the impact of remittances on economic growth in Latin America and the Caribbean? International Advances in Economic Research, 19(3), 273-288. http://doi.org/10.1007/s11294-0139407-2

Record high remittances sent globally in 2018. World Bank. (2019, April 8). https://www.worldbank.org/en/news/press-release/2019/04/08/record-high-remittancessent-globally-in-2018. 


\section{Macrothink}

Sutradhar, S. R. (2020). The impact of remittances on economic growth in Bangladesh, India, Pakistan and Sri Lanka. International Journal of Economic Policy Studies, 14(1), 275295. https://doi.org/10.1007/s42495-020-00034-1

Ustubici, A., \& Irdam, D. (2012). The impact of remittances on human development: a quantitative analysis and policy implications. Economics \& Sociology, 5(1), 74-95. https://doi.org/10.14254/2071-789x.2012/5-1/6

World Bank predicts sharpest decline of remittances in recent history. World Bank. (2020, April 22). Retrieved from https:/www.worldbank.org/en/news/pressrelease/2020/04/22/world-bank-predicts-sharpest-decline-of-remittances-in-recenthistory.

\section{Appendix}

\section{Figures and Graphs}

\section{LOGGDP}

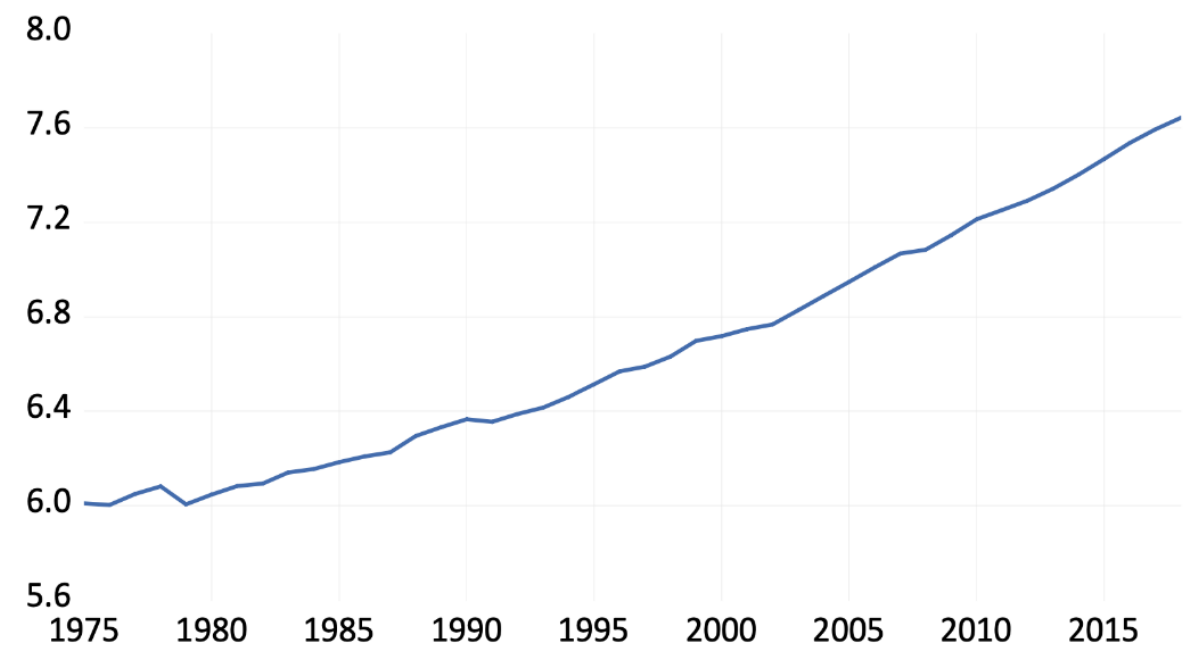

Figure A1. Level Graph of $\log$ GDP 
DLOGGDP

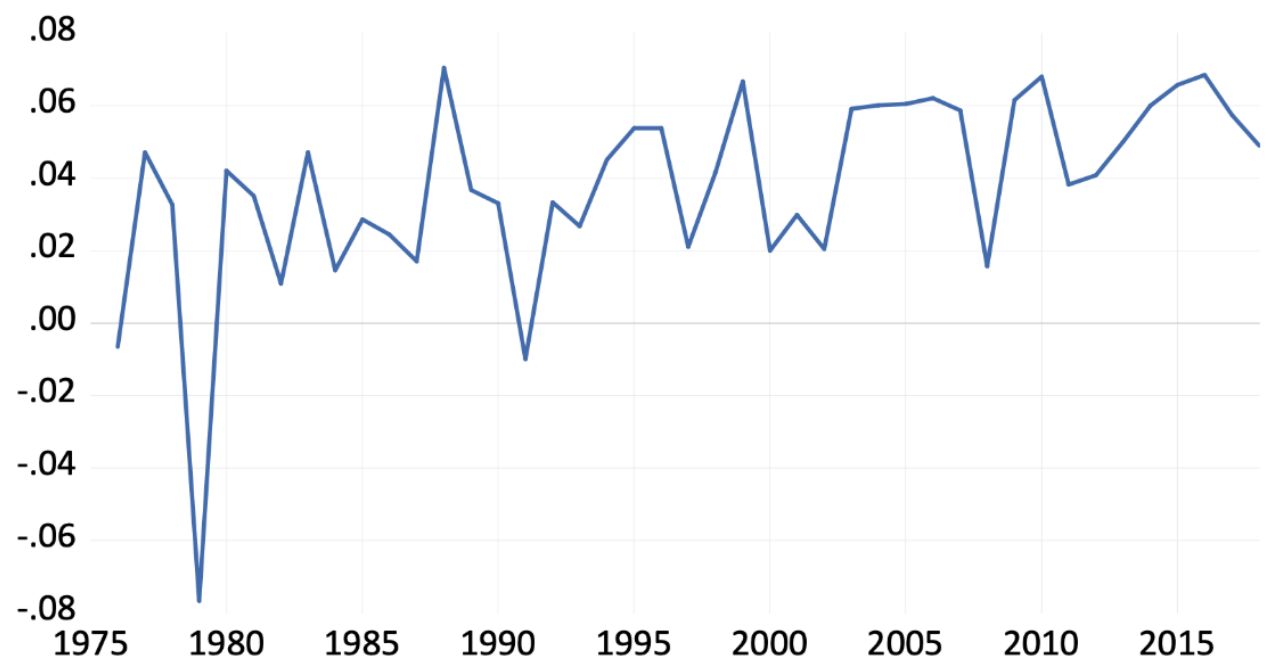

Figure A2. First Differenced Graph of logGDP
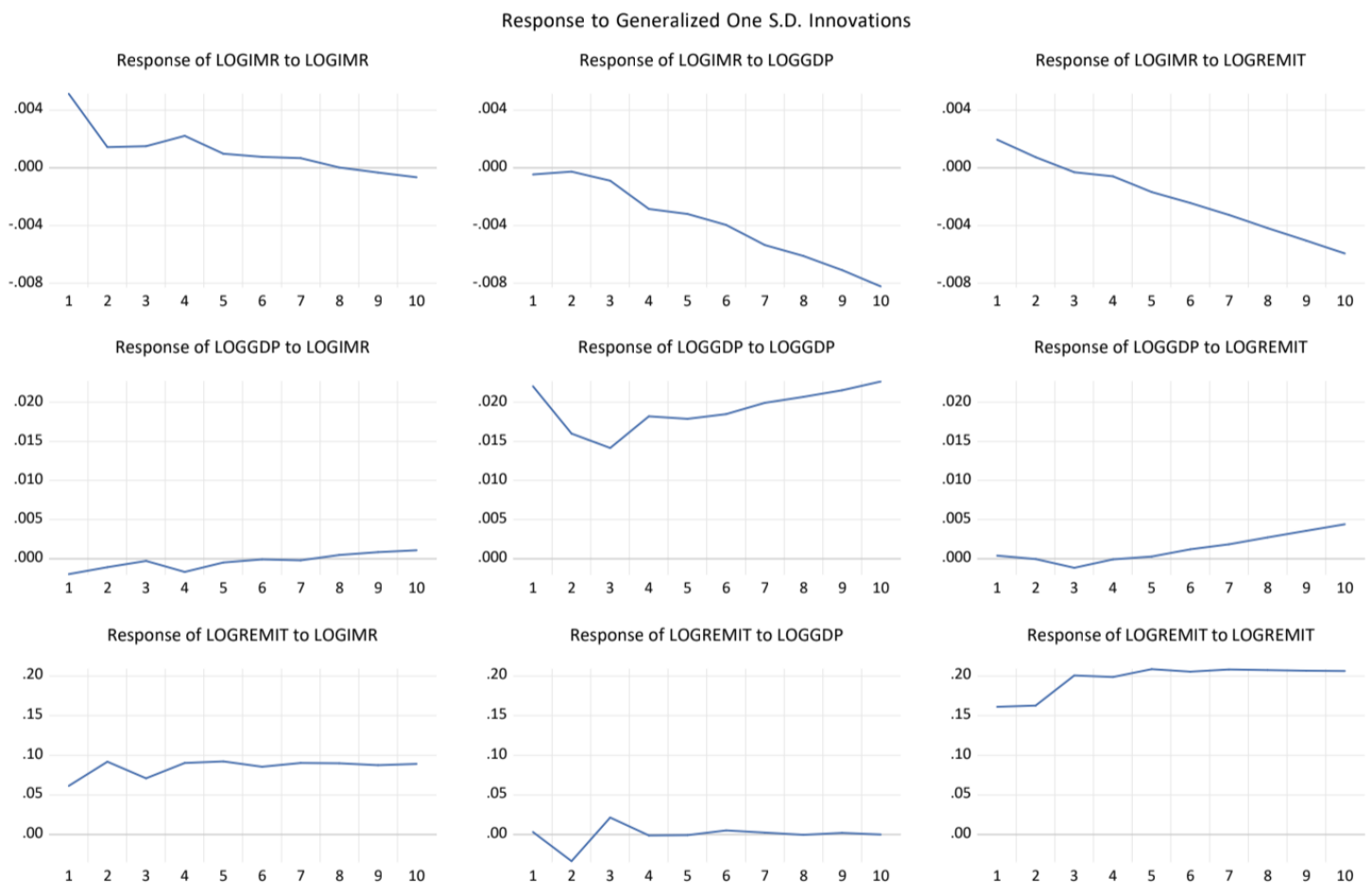

Figure A3. Impulse Response Functions 


\section{Copyrights}

Copyright for this article is retained by the authors, with first publication rights granted to the journal.

This is an open-access article distributed under the terms and conditions of the Creative Commons Attribution license (http://creativecommons.org/licenses/by/4.0/) 